This paper is a post-print of an article published in Contemporary Political Theory 2(1) 2003: 77-87. The definitive version is available at: http://www.palgravejournals.com/cpt/journal/v2/n1/abs/9300071a.htm

\title{
Political Grounds for Forgiveness
}

\author{
Andrew Schaap
}

This article is intended as a response rather than counterpoint to Bennett's careful argument that amnesty cannot amount to an act of collective forgiveness. I agree that a state cannot forgive perpetrators of grave human rights violations. However, I am concerned that conceiving the question of amnesty strictly in terms of a choice between the Art of Compromise or the Hard Line of retribution may unduly limit our understanding of the potential relation between amnesty and forgiveness in politics. To show this, I consider the question of amnesty in relation to the possibility of forgiving those ordinary citizens implicated in the perpetration of wrongs as bystanders and beneficiaries of an unjust regime. Following Arendt, I argue that political grounds for forgiveness in such circumstances are the frailty of the world (our intersubjective sense of reality) and the natality of the other (her capacity for initiatory action). On this account, forgiveness is not necessarily the final term in a process of reconciliation that restores a wrongdoer to the moral community. Rather, the disposition to forgive makes possible a politics in which members of a divided polity contest each other's understandings of the violence of the past and its significance for their political association.

Keywords: amnesty; Arendt; forgiveness; reconciliation; transitional justice

If the moral achievement of retributive justice is that it holds the individual to account for his actions and refuses to accept excuses such as 'just following orders', this can also be its political failure. For, as de Grieff $(1996,105)$ points out, imputing criminal guilt to particular individuals tends to exonerate those implicated in past wrongs as tacit supporters or beneficiaries of an unjust regime. Of course, amnesty is even more likely to obscure political responsibility for past wrongs. Punishment, at least, symbolizes a collective condemnation of past wrongs. Amnesty, by contrast, suggests collective forgetting, a failure to take past wrongs seriously at all. To add insult to injury, as Bennett argues, when amnesty is misrepresented as forgiveness rather than acknowledged as the strategic compromise it really is, this failure is passed off as a moral achievement. What was interesting in South Africa, however, was that amnesty was linked to reckoning with the past rather than wiping the slate clean. As van Roermund $(2001,178)$ 
neatly puts it, amnesty was associated with 'anamnesis rather than amnesia'. The deal of granting amnesty in return for full disclosure of the truth was supposed to provide a way of burying rather than obliterating the past, 'a way of covering that uncovers the meaning of what has happened'.

Bennett argues persuasively that amnesty cannot be justified in terms of forgiveness. Consequently, we are left with a stark choice between the moral reasoning of the Hard Liner that being true to the past requires retributive justice and the political willingness of the Compromiser to forget past wrongs for the sake of a common future. Reducing the question of amnesty to these terms, however, seems to miss something important about what was aspired to in South Africa. This may not have amounted to another kind of justice, but it did appear to involve more than just realpolitik. Although I agree with Bennett that amnesty cannot be justified as a collective act of forgiveness, I want to suggest that a more subtle relation might sometimes emerge between amnesty, forgiveness and political reconciliation. In some circumstances, a willingness to forgive might sustain a policy of amnesty and, conversely, amnesty might contribute to the possibility of political forgiveness. To show this, I consider what might constitute political grounds for forgiving not those state agents who are criminally responsible for human rights violations, but those 'ordinary citizens' who are politically implicated in them.

Bennett (2002) understands forgiveness as the final term of reconciliation. Given the alienation engendered by wrongdoing and following repentance and atonement on the part of the wrongdoers, forgiveness on the part of those wronged announces the restoration of community between them. To forgive without first holding the wrongdoer to account is, thus, to concede too much too soon. It is to accept a relationship with the other on terms that fail to address adequately the moral truth of what went before. Retribution is required before forgiveness in order to affirm a commitment to shared norms. This restorative conception of reconciliation offers a powerful account of the moral psychology involved in the way we commonly respond to and seek to ameliorate wrongdoing. However, it is unpolitical because it presumes community rather than recognizing this as the contingent outcome of political interaction. When conceived in this way, the initiation of reconciliation depends, first, on establishing a moral consensus concerning what went before. However, it is precisely such a 
consensus that is likely to be lacking in a polity divided by grave state wrongs.

In order to conceive reconciliation politically it may be that we need to reverse the order of our thinking. In certain circumstances, it may be that forgiveness 'makes politics itself possible' (Elshtain, 2001, 53). Rather than achieving closure by restoring social harmony, wanting to forgive creates a space for truth-telling. As such, it opens the possibility of an interpretative struggle over the significance of past wrongs and the terms of political association (van Roermund, 2001, 179-181; Norval, 1998, 260-261). I follow Arendt (1998) in taking politics to entail an incessant contest over the meaning of events and actions for a world held in common. Insofar as forgiveness is political, then, it is not so much oriented to restoring wrongdoers to a moral community, but to disclosing the commonness of a world that is constituted by diverse and possibly incommensurable perspectives. As such, a disposition to forgive, indeed, describes an attitude with which we might come to politics, one which might enable us to work out and sustain a good we hold in common. However, contrary to the Hard Liner, it is not conditional on a prior moral consensus and recognition of common political authority. Rather, political forgiveness opens the way to their realization.

Fundamentally, forgiveness involves not only renouncing one's just claims against an other but overcoming a resentful view of her as 'the one who wronged me' (Hampton, 1988a, 38). In overcoming resentment we open ourselves to an understanding of the other that is more encompassing than her singular relation to us as our transgressor. Yet this is not accomplished easily. We quite properly feel resentful when wronged. What we resent is not simply the material harm inflicted on us, but the insulting message a wrong carries with it. In wronging us, the other reveals her contempt for us by treating us as her inferior. Resentment fights what our transgressor's act denies. It insists on the wrongness of the act and our entitlement to proper treatment (Hieronymi, 2001, 547; Murphy, 1988, 25). We are right to be suspicious, then, of the quietism implicit in making a political virtue out of a disposition to forgive. Failure to resent and protest a wrong might indicate a lack of self-respect, a willingness to condone wrongdoing for the sake of maintaining a relationship. Resentment often serves an important role in public life by drawing attention to the rights and respect due to members of a group. Yet to persist in resenting the other 
may be to fixate on grievances and historical events that reinforce a group's sense of injustice and dishonour. The establishment of friendly civic relations in a polity divided by past wrongs depends upon the possibility of relinquishing the hard feelings occasioned by such collective memories without forgetting or condoning what went before.

While it might not be possible to forgive as a simple act of will, it is certainly possible to want to forgive, to seek grounds for forgiveness that enable us to relinquish our hard feelings. However, political grounds for forgiveness cannot amount to reasons why we ought to forgive. Grounds for forgiveness cannot be conceived in terms of rights and duties. For to demand reasons why one ought to forgive, as the Hard Liner does, is to assume an unforgiving attitude. As Calhoun $(1992,80)$ points out, if forgiveness is made conditional on desert then it either becomes unjustified (because undeserved) or redundant (because it offers only what is rightly due) (see also Kolnai, 1977). For forgiveness to be meaningful, it must be offered freely. Forgiveness, therefore, is only meaningful in relation to an other who justly warrants our continued resentment.

To insist that we can only forgive the undeserving, however, is not necessarily to reduce forgiveness to the Art of Compromise, as Bennett suggests. Calhoun (1992) provides an insightful account of how one can be true to the past without making forgiveness conditional on the wrongdoer's repudiation of her acts. Grounds for the 'aspirational forgiveness' Calhoun advocates are revealed to us through telling a story that makes biographical, but not necessarily moral, sense of how the other could wrong us. Such a story is not intended to show the other as one worthy of forgiveness by separating the sin from the sinner. Rather, it situates the wrongs done against us in the biographical context within which the other makes sense of her own actions. This leads to a kind of understanding that confirms our perception of the past and the injury perpetrated against us. However, it does not demand that the one who wronged us be different from what she is. We find grounds for overcoming resentment by making our transgressors' actions intelligible 'by forgivingly understanding how they have made sense of their lives' (Calhoun, 1992, 96). Importantly, in the context of a reconciliatory politics, this means engaging with the collective meanings and narratives by which our former enemy might have made sense of his life as, for instance, a freedom fighter rather than a terrorist.

If this phenomenology of forgiveness is accurate, then it is clear that 
neither the Art of Compromise advocated by the political realist nor the Hard Line taken by the political liberal can furnish adequate grounds for forgiveness in public life. If politics is a struggle for power between actors with competing interests, then a forgiving disposition is either soft-headed or it cloaks the particular interest an actor is really pursuing. According to the Art of Compromise, necessity is the only ground for forgiveness in politics. The need to forgive arises from a 'responsibility to the future', which comes from weighing 'objective interests that come into play' (Weber, 1948, 116). We 'forgive' only when we have to, when political reality dictates that the only responsible course of action is to relinquish our just claims against a stronger other. Yet, as Bennett argues, this is not forgiveness at all because it is bargained away rather than offered freely.

If politics is the public means through which the private freedoms of individuals are secured, then forgiveness is appropriate in the public sphere only if it does not exceed or compromise the rights and duties of citizen appropriate for a plural society. For the Hard Liner, forgiveness must be grounded on reason. We ought to forgive only if this is compatible with the dictates of justice and we need only forgive to the extent that this makes possible the minimal level of civility necessary to maintain peaceful civic relations. Forgiveness either becomes redundant (because subordinated to justice) or it is limited to merely tolerating (rather than overcoming resentment towards) one's transgressor (e.g. see Digeser, 1998).

An Arendtian (1998, 230-247) account of politics, by contrast, affords forgiveness an indispensable role in political life. On this account, humans depend upon political association not only to guarantee their mutual security but also to experience meaning. The need for forgiveness arises in politics because of the predicament of non-sovereign freedom. Arendt conceives freedom in terms of natality. Just as each birth constitutes a new beginning in the world, so human agents are free when they act, not simply to choose between pre-given ends, but to begin something entirely new. Yet this freedom is nonsovereign in that we lack mastery over the consequences of our actions. This is so because we always act among a plurality of agents who share our capacity for initiatory action.

The predicament of non-sovereign freedom is the source of the haphazardness and moral irresponsibility of political life. Through 
action we initiate processes in the world that are boundless, unpredictable and irreversible because every act always falls into an already existing web of conflicting wills and intentions. Processes initiated through a single act have the potential of enduring indefinitely in the world. Not only does each process outlast its initiating act, but it tends to grow in strength and multiply in its consequences as it is carried through the web of human relations. The intersubjective world is rendered frail by this boundlessness of action, its 'inherent tendency to force open all limitations and cut across all boundaries' (Arendt, 1998, 190). The multiple re-actions and counter reactions to an original wrong can develop into a protracted conflict, which threatens to undermine a fragile sense of a common reality that sustains civic relations. Yet the risk of action is unavoidable because the disclosure of a common world depends on the inter-action of natal beings to produce the stories that are the source of meaning in human affairs.

Political grounds for forgiveness stem from a recognition of this predicament of non-sovereign freedom. These grounds are the frailty, of the world and the natality of the other. Forgiveness is an appropriate response to frailty, since it saves the world from ruin by bringing to an end re-active processes that might otherwise endure indefinitely in the web of human relations. As response to natality, forgiveness releases the other from the consequences of her action. As long as an actor remains bound to the consequences of an original act, her capacity to act anew is reduced. By no longer holding her to account, forgiveness frees the other to engage in the play of the world. In its moment of care, as response to the frailty of the world, forgiveness brings a process of inter-action to an end. In its initiatory moment, as response to the natality of the other, it establishes the possibility of a new beginning.

The achievement of forgiveness, writes Arendt $(1998,237)$, is that it "serves to undo the deeds of the past, whose "sins" hang like Damocles' sword over every new generation'. However, since the consequences of our actions are irreversible, the deeds of the past cannot be undone in any literal sense. Rather, what forgiveness undoes is the meaning of an original wrong. Since the end of politics is the generation of relationships and the experience of meaning, a political undertaking to forgive is a struggle to settle the meaning of the wrongful act in the past for the sake of our life in common. To forgive is thus to resist the power of the past to determine the possibilities of the present. A past wrong may 'persist as a present threat' to a particular 
category of people within a polity so long as its memory remains as a testament to their inferior social status (Hieronymi, 2001, 548f). As Hampton $(1988 \mathrm{~b}, 129)$ discusses, punishment undoes the meaning of a wrong by the communal negation of the claim to superiority implicit in the wrongdoer's original act. When a crime goes unpunished what the criminal gets away with is this false claim to superiority. Punishment annuls the insulting message of the wrong by symbolically defeating the perpetrator on behalf of the victim. Similarly, an apology is intended to undo the meaning of a wrong by withdrawing endorsement of the insulting message one's act communicated.

As a response to the frailty of the world, forgiveness undoes the meaning of a wrong by bringing to an end the story that continues to implicate the other in an original transgression. In doing so, it leaves the meaning of the event in the past. Trust is ventured in this moment, since it involves a suspension of judgement or what Elshtain $(2001,43)$ calls 'knowing forgetting'. What is suspended is not judgement of the wrongness of the act, but the judgement that this confirms the other as one's enemy in the present. Trust is ventured for the sake of establishing a new relation based on mutual recognition of each other as co-builders of a common world. Respect for the other as co-builder of a common world, which is the basis for political forgiveness, differs from that Kantian form of respect that applies to individuals as autonomous beings who share the universal capacity for reason. Instead, it applies to individuals as political beings who share a particular world as their common end. As such it presupposes an interdependence based not only on our shared need for security but also on the presence and acting of others for a sense of the reality and worth of things.

Through engaging in an incessant discourse about this world, 'we' invest it with meaning. The disclosure of a world thus also entails the constitution of a 'we'. Although social reality opens up to each of us in different ways, the fact of it being perceived in common is felt. The 'we' that emerges from this common sense of the world is fragile because it depends on our speaking and acting in public for it to be brought into being. To forgive the other for the sake of the fragile world one holds in common with her is, therefore, to forgive her in her neighbourly relation to us rather than on the basis of our shared moral status as rational beings or creatures of God. This entails a kind of political humility, an attitude of care and moderation. We forgive 
because we may also need to be forgiven. For only one so full of hubris to believe that he has no need of forgiveness could wish to live in an unforgiving world. In being politically disposed to forgive, then, one discounts the historical fact of oppression as evidence of moral superiority or collective innocence. The possibility of forgiveness depends in this way on an 'awareness that there is a virtual reciprocity in what the oppressors did to the oppressed' and, consequently, that those wronged were on the side of good as a matter of historical fact, not as a matter of principle, that is, 'not because they are the good people' (van Roermund, 2001, 182-183). It involves an awareness of evil as mundane in the simple but profound sense that it is not metaphysical but 'of the world'.

As response to the natality of the other, forgiveness undoes the meaning of the wrong by ceasing to define him in terms of his past actions. We undo the meaning of the deed as evidence of the identity of the other. As Arendt $(1968,248)$ puts it, to forgive in this sense is to insist on seeing the individual as "more than whatever he did or achieved'. This initiatory moment of forgiveness is hopeful since it is predicated on the potential inherent in the other to begin anew. To forgive for the sake of who the other is, is to release him from the consequences of his actions so that he can remain a free agent. We forgive the other 'what' he is (our transgressor) for the sake of 'who' he might reveal himself to be through acting in the world.

The release that forgiveness offers in its initiatory moment is indispensable in politics in order to mitigate against despair at the moral irresponsibility and haphazardness that arises from the predicament of non-sovereign freedom. Care for the world must balance, but not overwhelm that agonistic striving through which the difference of individuals and the commonness of the world is disclosed. When care overwhelms the agent it gives rise to depressive guilt, a surfeit of which leads to withdrawal from the world for fear of being implicated in political injustice. It is in this context that the possibility of forgiveness allows us to remain free agents, willing participants in the play of the world. In its initiatory moment, then, forgiveness affirms our shared potentiality to act anew. Indeed, forgiveness resembles action because of its miraculousness and spontaneity. Forgiveness reveals the natality of the forgiver since, in contrast to retaliation, it is not a predictable reaction. Rather it is a response that is both unexpected and unpredictable. 
Natality is the source of that 'boldly, venturesomely aspiring and active pursuit of Value' that animates forgiveness as a supererogatory act (Kolnai, 1977, 233).

An Arendtian account of the political is thus able to furnish us with political grounds for forgiveness, which are not reducible either to the Art of Compromise or the Hard Line of retributive justice. If forgiving for the sake of a fragile world has an affinity with the Art of Compromise, it differs in that it is not predicated on a consequentialist morality. This is so since the struggle to settle the meaning of the wrong in the past is not the same as forgetting or 'overcoming' the past. Rather, it seeks to establish a provisional closure, one that acknowledges the persistent claims of the past in the present $\mathrm{F}$ and, therefore, the impossibility of any final reconciliation $\mathrm{F}$ but resists the power of the past to determine the possibilities of the present (Norval, 1998, 260-261).

Whereas forgiveness is retrospective in its moment of care, it is prospective as an initiatory act. In forgiving we affirm our potentiality to act anew, to establish new relations. However, since this is an inherently free act, its terms cannot be dictated by the demands of justice. The way of political forgiveness does not necessarily follow the logic of right that the Hard Liner insists on. Rather, the willingness to forgive invites the other to politics. Instead of presupposing community between wrongdoers and wronged, a 'we' is invoked as a matter of faith, in terms of which former enemies might come to a shared understanding of what went before. In South Africa, for instance, it was not the acknowledgement of wrongdoing by perpetrators, which opened the way to forgiveness. Rather, it was the disposition to forgive, a willingness on the part of those wronged to defer the right to just retribution, that cleared the way for perpetrators to publicly disclose the wrongdoing they were involved in (van Roermund, 2001, 179-183).

Yet, although we might recognize the indispensability of forgiveness in everyday political life, we might wonder about its applicability in relation to grave state wrongs. Striving for forgiveness between ordinary citizens divided by such wrongs is hard enough, but applying this to perpetrators seems impossible. I agree with Bennett that amnesty cannot be a form of collective forgiveness for the simple reason that no state can have the authority to forgive on behalf of the victims. However, there is a relation between amnesty and the kind of political 
forgiveness between ordinary citizens I have been talking about, which stems from the kind of making sense of perpetrator's actions that has recently been attempted in South Africa.

Amnesty in South Africa was conditional not on a perpetrator's showing remorse (seeking forgiveness the hard way), but in making a full disclosure of wrongdoing and showing this to be associated with a political objective. In an insightful commentary, Veitch (2001) discusses how this meant that the amnesty commission had to judge applicants both as individuals who committed isolated crimes and as members of a class who were pursuing political objectives. As Veitch $(2001,39)$ puts it, judges were called on 'to make an overt judgement about the 'political objective' of the offence, and in so doing necessarily engage a collective meaning for both the offence and applicant's role in its commission' and somehow understand this to 'fit the "full disclosure" unique to the applicant'. It was this effort to make political sense of perpetrators' actions, one that necessarily deprioritized Right, which linked it with a wider struggle for political forgiveness. For, in associating individuals, acts with political objectives, the amnesty process implicated all those on behalf of whom perpetrators claimed to be acting.

In this context, the truth the TRC sought to disclose was not the truth of the event, but the 'truth of memory' (Veitch, 2001, 40). The connection between political objective and full disclosure drew the amnesty applicants and the law into a political reassessment of the past, one which demanded a confrontation between actors' selfunderstandings then and now. Being true to the past, in this sense, required both making political sense of how wrongs came to be perpetrated as well as the moral judgement that these acts were wrong. By making political sense of past wrongs those social meanings that structured the perpetrator's actions and that make his choice of evil comprehensible come to the fore. To be sure, granting amnesty based on such an understanding could not amount to a collective act of forgiveness. Yet, the amnesty process seemed to be, at least in part sustained by a wanting to forgive, just as the truth-telling associated with amnesty made way for a wider process of political forgiveness by engaging the collective meanings perpetrators shared with ordinary citizens.

Following Arendt, then, I have tried to show that there may be grounds for forgiveness in politics that differ from those insisted on by 
the Hard Liner but, yet, are not reducible to the realpolitik of the Compromiser. Forgiving for the sake of the natality of our transgressor is not the same as the forgetfulness advocated by the Compromiser. For in doing so, we seek a provisional end to the story that identifies the other as our enemy rather than simply ceasing to tell a story at all. Yet, forgiving for the sake of a fragile world may lead us to defer the right to the just retribution advocated by the Hard Liner in order to create a space for politics between us and our transgressor. Rather than insisting that forgiveness depends on first establishing the moral truth of what went before, a willingness to forgive establishes a context within which we might contest the significance of past wrongs for the world that lies between us. In a society divided by state wrongs, the possibility of reconciliation might sometimes depend on the willingness on the part of a brave few to forgo the certainty of moral reason for the risk of politics.

\section{Notes}

1 Earlier versions of this article were presented at the Human Rights and Human Frailty conference at the University of West of England in September 2001 and at the Social and Political Theory Seminar at the University of Edinburgh in October 2001. I am grateful to the participants at these forums for their challenging responses. Special thanks are due to Chris Bennett, Emilios Christodoulidis, Kim Hutchings, Russell Keat, Zenon Bankowski, Keith Breen and the reviewers for their insightful comments.

2 Conversely, it is because he appeals to the necessity of circumstance associated with the political emergency or war that our wrongdoer will express only regret and not remorse for the harms he has inflicted on us.

3 Elshtain $(2001,43)$ writes: 'Forgetting, in this case, does not mean that one falls into radical present-mindedness and the delusion that the past counts for nothing; rather, one assesses and judges just what the past does count for in the present $F$ how much it should frame, shape, and even determine present events'.

$4 \mathrm{I}$ am indebted to Zenon Bankowski for pointing out to me how forgiving sometimes involves suspending judgement. I think this is what Arendt is getting at when she looks for non-theological terms for forgiveness as dismissing or releasing the other. Similarly, she prefers trespassing, missing, failing and going astray to 'sinnning' and changing one's mind, returning, retracing one's steps to 'repenting' (Arendt, 1998, p. 240, n. 78).

5 Though our sense of morality depends upon recognizing a universal quality in the other such as dignity or sacredness on the basis of which we accord rights to all, this quality cannot be attributed to human nature but must be articulated and actualized through our belonging within particular associations. As Arendt (1968, 81-82) writes, 'Philosophy may conceive of the earth as the homeland of mankind and of 
one unwritten law, eternal and valid for all. Politics deals with men, nationals of many countries and heirs to many pasts; its laws are the positively established fences which hedge in, protect, and limit the space in which freedom is not a concept, but a living, political reality.'

6 To recognize evil as mundane is to recognize, as van Roermund (2001, p. 183) writes, 'that what the oppressors did to the oppressed belongs to the evil humans do to each other, and not to a mythic evil that intrudes on the world of humans from outside. In reconciliation, evil becomes "ordinary" in the profound sense of "'among us',',

7 This understanding of forgiveness as a miraculous but everyday occurrence is preferable to the metaphor of forgiveness as gift. For, while it emphasizes the elective quality of forgiveness, it does not presuppose an understanding of responsibility in terms of a kind of moral accounting. Rather, it allows for a richer understanding of responsibility as a responsiveness to the particular (see Ricoeur, 2000; Schaap, 2001, 758-763).

\section{References}

Arendt, H. (1968) Men in Dark Times, New York \& London: Harcourt Brace \& Company.

Arendt, H. (1998) The Human Condition, 2nd ed, Chicago: University of Chicago Press.

Bennett, C. (2002) 'The varieties of retributive experience', The Philosophical Quarterly 52(207): 145-163.

Calhoun, C. (1992) 'Changing one's heart', Ethics 103: 76-96.

Digeser, P. (1998) 'Forgiveness and politics: dirty hands and imperfect procedures', Political Theory 26(5): 700-724.

de Grieff, P. (1996) 'Trial and punishment: pardon and oblivion', Philosophy and Social Criticism 22(3): 93-111.

Elshtain, J. (2001) 'Politics and Forgiveness', in N. Biggar (ed.) Burying the Past, Washington, DC: Georgetown University Press.

Hampton, J. (1988a) 'Forgiveness, Resentment and Hatred', in J. Murphy and J. Hampton (eds.) Forgiveness and Mercy, Cambridge: Cambridge University Press.

Hampton, J. (1988b) 'The Retributive Idea', in J. Murphy and J. Hampton (eds.) Forgiveness and Mercy, Cambridge: Cambridge University Press.

Hieronymi, P. (2001) 'Articulating an uncompromising forgiveness', Philosophy and Phenomenological Research 62(3): 529-555.

Kolnai, A. (1977) 'Forgiveness', in Ethics, Value and Reality: Selected Papers of Aurel Kolnai, London: The Althone Press.

Murphy, J. (1988) 'Forgiveness and Resentment', in J. Murphy and J. Hampton (eds.) Forgiveness and Mercy, Cambridge: Cambridge University Press.

Norval, A. (1998) 'Memory, identity and the (im)possibility of reconciliation: the work of the Truth and Reconciliation Commission in South Africa', Constellations 5(2): 250-265. 
Ricoeur, P. (2000) 'The concept of responsibility' in D. Pellauer (trans.), The Just, Chicago: University of Chicago Press.

Schaap, A. (2001) 'Guilty subjects and political responsibility: Arendt, Jaspers and the resonance of the 'German question' in politics of reconciliation', Political Studies 49(4): 749-766.

van Roermund, B. (2001) 'Rubbing off and Rubbing on: the Grammar of reconciliation', in E. Christodoulidis and S. Veitch (eds.) Lethe's Law: Justice, Law and Ethics in Reconciliation, Oxford \& Portland: Hart Publishing.

Veitch, S. (2001) 'The Legal Politics of Amnesty', in E. Christodoulidis and S. Veitch (eds.) Lethe's Law: Justice, Law and Ethics in Reconciliation, Oxford \& Portland: Hart Publishing.

Weber, M. (1948) 'Politics as a Vocation', in H.H. Gerth and W. Mills (trans.), From Max Weber: Essays in Sociology, London: Routledge \& Kegan Paul. 


\section{University Library}

\section{- M M I N E R VA A gateway to Melbourne's research publications}

Minerva Access is the Institutional Repository of The University of Melbourne

Author/s:

Schaap, Andrew

Title:

Political grounds for forgiveness

Date:

2003-03

Citation:

Schaap, A. (2003). Political grounds for forgiveness. Contemporary Political Theory, 2(1), 77-87.

Publication Status:

Published

Persistent Link:

http://hdl.handle.net/11343/34376 